\title{
PENERAPAN SOLUTION-FOCUSED BRIEF GROUP THERAPY (SFBGT) UNTUK MENINGKATKAN SELF-ESTEEM REMAJA PUTRA DI PANTI ASUHAN X
}

\author{
Grace Eugenia Sameve $^{1}$, Debora Basaria ${ }^{2}$ dan Santy Yanuar Pranawati ${ }^{3}$ \\ ${ }^{1}$ Fakultas Psikologi, Universitas Tarumanagara Jakarta \\ Email: gesameve@gmail.com \\ ${ }^{2}$ Fakultas Psikologi, Universitas Tarumanagara Jakarta \\ Email: deborab@fpsi.untar.ac.id \\ ${ }^{3}$ Fakultas Psikologi, Universitas Tarumanagara Jakarta \\ Email: santyyp@gmail.com
}

\begin{abstract}
ABSTRAK
Self-esteem merupakan satu aspek diri yang mengalami perubahan yang berarti pada masa remaja. Selain perkembangan kognitif dan pembentukan self-identity, self-esteem pada remaja juga dipengaruhi oleh kondisi ekonomi serta dukungan yang diterima dari orang tua. Mengingat dampak yang dikontribusikan self-esteem terhadap berbagai aspek kehidupan remaja, diperlukan suatu intervensi untuk memastikan bahwa individu tidak memiliki tingkat self-esteem yang rendah selama masa ini. Oleh sebab itu, Solution-Focused Brief Group Therapy (SFBGT) diterapkan pada penelitian ini sebagai upaya untuk meningkatkan level self-esteem dari 5 remaja putra di panti asuhan $X$ yang berasal dari keluarga dengan kondisi ekonomi rendah dan mendapatkan dukungan yang terbatas baik dari keluarga maupun pengasuh. Kelima remaja ini memiliki keyakinan yang kurang akan diri sendiri dan memerlukan dorongan yang lebih sebelum akhirnya menunjukkan beberapa perilaku yang sebenarnya dapat dilakukan tanpa kesulitan yang berarti. Penelitian ini menggunakan quantitative one group pre-test post-test design dimana alat ukur State Self-Esteem Scale (SSES) dianalisa untuk mengetahui perbandingan hasil sebelum dan sesudah pemberian intervensi. Total skor dari tiga partisipan mengalami peningkatan, sedangkan total skor dari dua partisipan mengalami penurunan. Meskipun demikian, total skor yang diperoleh kelima partisipan menunjukkan bahwa self-esteem mereka berada dalam kategori rendah. Berdasarkan hasil, dapat disimpulkan bahwa efektivitas dari Solution-Focused Brief Group Therapy untuk meningkatkan self-esteem dari lima remaja putra di Panti Asuhan X tergolong kurang.
\end{abstract}

Kata kunci: Solution-Focused Brief Group Therapy, Self-Esteem, Remaja Putra, Panti Asuhan

\section{PENDAHULUAN}

\section{Latar belakang}

Self-esteem, atau keyakinan dan kepuasan terhadap diri sendiri, merupakan satu aspek diri yang memiliki peran penting pada tiap tahap kehidupan seseorang (Woolf et al., 1967). Self-esteem bukan hanya memberikan keyakinan serta sense of competence untuk menghadapi berbagai tantangan hidup, tetapi juga sangat mempengaruhi perilaku yang individu tunjukkan (Orth, Robins, \& Roberts, 2008; Trzesniewski et al., 2006).

Self-esteem seseorang akan terus menerus mengalami perubahan seiring dengan berjalannya waktu (Papalia, Olds \& Feldman, 2009). Meskipun demikian, perubahan yang signifikan diketahui terjadi pada masa remaja (Papalia, Olds \& Feldman, 2009; Wells, 2016). Selain perkembangan kognitif yang memungkinkan individu untuk membuat penilaian yang lebih kompleks akan diri sendiri, self-identity - yang merupakan satu komponen esensial dari selfesteem, juga terbentuk pada masa ini (Papalia, Olds \& Feldman, 2009; Wells, 2016). Self-esteem individu seringkali mengalami penurunan yang signifikan apabila individu tidak mendapatkan kesempatan yang cukup untuk, secara aktif, mencari dan membentuk sense of self yang koheren atau utuh pada masa ini. Di sisi lain, peningkatan pada self-esteem akan terjadi apabila individu dapat mencapai sense of self yang utuh setelah melalui proses eksplorasi yang aktif. 
Dua faktor lain yang diketahui memiliki pengaruh terhadap self-esteem remaja adalah kondisi ekonomi (socioeconomic status) dan dukungan yang diterima dari orang tua (Bean, Bush, McKenry \& Wilson, 2003; Mruk, 2006; Rhodes, Roffman, Reddy \& Fredriksen, 2004; Twenge \& Campbell, 2002). Pada penelitian yang dilakukan dengan 1804 remaja, Rhodes, Roffman, Reddy dan Fredriksen (2004) menemukan bahwa remaja dengan kondisi ekonomi rendah memiliki tingkat self-esteem yang lebih rendah dibandingkan remaja dengan kondisi ekonomi menengah ataupun atas. Twenge dan Campbell (2002), juga menemukan hubungan positif yang signifikan antara kondisi ekonomi dan self-esteem dimana individu dengan kondisi ekonomi lebih tinggi ditemukan memiliki tingkat self-esteem yang lebih tinggi, sedangkan individu dengan kondisi ekonomi lebih rendah memiliki tingkat self-esteem yang lebih rendah pula. Terkait dengan hubungan antara dukungan orang tua dan self-esteem remaja, penelitian Bean, Bush, McKenry dan Wilson (2003) menunjukkan bahwa dukungan orang tua merupakan satu faktor yang memprediksi tingkat self-esteem remaja. Pada penelitian yang dilakukan dengan 155 remaja, mereka menemukan bahwa semakin banyak jumlah dukungan yang diterima dari orang tua, semakin tinggi pula self-esteem yang dimiliki remaja. Di sisi lain, keterbatasan dan atau absence of support dari orang tua berdampak negatif pada self-esteem yang dimiliki remaja, terutama remaja laki-laki (Miller, 1984; Mruk, 2006).

Saat ini, Panti Asuhan $\mathrm{X}$, yang merupakan salah satu panti sosial asuhan anak di bilangan Jakarta Selatan, memiliki 18 anak asuh remaja yang berasal dari keluarga dengan status ekonomi yang rendah. Sementara penyediaan makanan yang cukup dapat mendukung proses perkembangan kognitif yang sedang terjadi pada setiap remaja ini, jumlah pengasuh yang terbatas membatasi perhatian, dukungan serta perlakuan individual yang diterima tiap individu (Kementrian Sosial, Save the Children \& UNICEF, 2007). Hal ini mengindikasikan bahwa dua faktor yang memiliki pengaruh negatif terhadap self-esteem remaja, yakni kondisi ekonomi rendah (low socioeconomic status) serta keterbatasan dukungan yang diterima dari figur orang tua - dalam hal ini termasuk pengasuh, dialami oleh anak asuh remaja di Panti Asuhan X.

Dari ke delapan belas remaja, lima diantaranya dinilai memiliki keyakinan yang kurang akan diri sendiri yang berdampak pada performa mereka sehari-hari. Ketika diklarifikasi, pengasuh menjelaskan bahwa kelima remaja memerlukan dorongan yang lebih sebelum akhirnya menunjukkan beberapa perilaku yang sebenarnya dapat dilakukan tanpa kesulitan yang berarti. Sebagai contoh, kelima remaja tersebut membutuhkan dorongan yang lebih untuk memimpin doa ataupun memimpin aktivitas keagamaan lain di depan anak asuh lain meskipun nilai pelajaran agama mereka tergolong cukup baik dibandingkan dengan anak lain. Adapun respons pertama yang seringkali mereka berikan ketika diinstruksikan untuk melakukan hal-hal yang sebenarnya cukup mereka kuasai adalah "Jangan saya Pak", "Yang lain aja Pak", "Kok saya Pak?" ataupun "Saya tidak bisa Pak". Selain itu, ketika ditanya mengenai hal-hal yang cukup mereka kuasai, Pak Y menjelaskan bahwa mereka seringkali memberikan respons yang terbatas dan disertai beberapa kata yang menunjukkan keragu-raguan, seperti "mungkin", "kayaknya" dan "kali". Keraguan yang serupa juga ditunjukkan ketika didorong untuk menyatakan pendapat dalam diskusi meskipun konten dari pernyataan yang diberikan pada dasarnya masuk akal dan sesuai dengan topik.

Mengingat dampak yang dikontribusikan self-esteem terhadap berbagai aspek kehidupan remaja, termasuk pada prestasi akademis, keterampilan sosial, kemampuan untuk merespons pada tantangan hidup serta kesehatan mental (Birndorf, Ryan \& Auinger, 2005; Mruk, 2006; Orth, Robins \& Roberts, 2008; Reasoner, 2002; Trzesniewski et al., 2006), maka proses terapi dengan pendekatan solution-focused akan dilakukan untuk meningkatkan self-esteem lima remaja asuh di 
Panti Asuhan X. Menurut Mruk (2006) dan Taathadi (2014), kemampuan untuk mendapatkan solusi yang efektif dan efisien untuk masalah, baik masalah besar maupun kecil, yang dihadapi dapat meningkatkan self-esteem individu. Brzezowski (2012) menyatakan bahwa solutionfocused brief group therapy merupakan jenis terapi ideal untuk individu yang berpartisipasi dalam intervensi karena rujukan pihak lain, dalam hal ini oleh panti asuhan X, karena pada terapi ini individu diajak untuk membicarakan hal yang perlu dilakukan untuk berubah, bukan untuk membicarakan masalah yang tidak ingin diakuinya. Terakhir, Mruk (2006) juga menambahkan bahwa kemampuan untuk memecahkan masalah dengan efektif bukan hanya meningkatkan peluang keberhasilan - satu faktor yang memiliki kontribusi terhadap proses evaluasi kompetensi diri yang melibatkan aspek kognisi, tetapi juga meningkatkan kesadaran serta assurance individu akan kekuatan atau strength yang dimilikinya.

\section{Rumusan masalah}

Apakah solution-focused brief group therapy (SFBGT) dapat diterapkan untuk meningkatkan self-esteem remaja putra pada di panti asuhan $\mathrm{X}$ ?

\section{Tujuan penelitian}

Tujuan dari penelitian ini adalah menerapkan solution-focused brief group therapy (SFBGT) sebagai upaya meningkatkan self-esteem remaja putra/pria di panti asuhan $\mathrm{X}$

\section{METODE PENELITIAN}

Partisipan penelitian. Lima remaja putra yang berpartisipasi dalam SFBGT memiliki karakteristik sebagai berikut: (a) berada dalam tahapan usia remaja (13-16 tahun), (b) telah menetap di panti asuhan X selama setidaknya 2 tahun karena kondisi ekonomi keluarga rendah, (c) memperoleh skor intelegensi yang termasuk dalam golongan rata-rata atau di atas rata-rata, dan (d) memperoleh skor yang lebih rendah dari $76($ skor $=<76)$ pada alat ukur State Self-Esteem Scale dengan skor yang lebih rendah dari 27 (skor $=<27$ ) pada domain sosial.

Desain penelitian. Penelitian ini menggunakan quantitative one group pre-test post-test design dimana kuesioner State Self-Esteem Scale dianalisa untuk mengetahui perbandingan hasil sebelum dan sesudah pemberian intervensi.

Lokasi penelitian. Penelitian ini dilakukan di panti asuhan X - Panti asuhan yang diperuntukkan bagi anak laki-laki yang merupakan seorang anak yatim, piatu, yatim piatu, terlantar, anak dengan orang tua miskin, sakitan atau anak dengan keluarga retak. Panti asuhan $\mathrm{X}$ berlokasi di Jakarta Selatan.

Instrumen penelitian. Peralatan yang digunakan dalam penelitian ini meliputi lembar informed consent, alat ukur State Self-Esteem Scale yang dikembangkan oleh Heatherton dan Polivy (1991), alat ukur Standard Progressive Matrices, lembar observasi, lembar wawancara, alat tulis, lembar aktivitas dalam manual solution-focused practice: An NSPCC toolkit for working with children and young people, kertas A2, kertas A4, kertas notes, spidol berwarna, double-sided tape, LEGO blocks, cat poster, kuas, palet, pensil warna dan snacks.

Pengukuran. State Self-Esteem Scale digunakan untuk mengukur dependent variable dari penelitian ini, yakni self-esteem Instrumen ini terdiri dari 20 items pertanyaan yang dikelompokkan menjadi 3 komponen self-esteem, yakni performance self-esteem (mis. 'Saya merasa yakin dengan kemampuan yang saya miliki'), social self-esteem (mis. 'Saya khawatir termasuk dalam kategori orang yang gagal') dan appearance self-esteem ('Saya merasa puas 
dengan penampilan tubuh saya saat ini'). Tiga belas dari 20 item pernyataan merupakan reverse scored items ('Saya merasa bahwa saya tidak berprestasi atau menunjukkan kinerja yang baik'). Setiap item pertanyaan memiliki 5 pilihan respons yang harus dipilih berdasarkan perasaan individu (STS = Sangat Tidak Sesuai dengan diri saya; TS = Tidak Sesuai dengan diri saya; KK = Kadang-Kadang sesuai dengan diri saya; $\mathrm{S}=$ Sesuai dengan diri saya; $\mathrm{SS}=$ Sangat Sesuai dengan diri saya).

Prosedur penelitian. Setelah kelima remaja putra dirujuk oleh pihak panti asuhan X, pre-test untuk mengetahui tingkat self-esteem mereka dilakukan dengan mengadministrasikan State SelfEsteem Scale. Wawancara autoanamnesa dengan kelima remaja juga dilaksanakan untuk mengetahui gambaran partisipan. Alat ukur State Self-Esteem Scale akan kembali diadministrasikan setelah sesi terakhir dari intervensi dilaksanakan sebagai post-test. Hasil pretest dan post-test kemudian akan dibandingkan untuk mengetahui dampak dari program intervensi terhadap tingkat self-esteem dari kelima remaja

Pelaksanaan intervensi. Intervensi solution-focused brief therapy yang dijalankan berjumlah 6 sesi. Durasi dari setiap sesi akan berkisar antara 50 hingga 80 menit. Sesi pertama dilaksanakan pada tanggal 23 Mei 2017 dan sesi kedua dilaksanakan pada tanggal 29 Mei 2017. Sesi ke 3 dilaksanakan pada tanggal 31 Mei 2017. Sesi keempat hingga keenam dilaksanakan selama 3 hari berturut-turut, yakni pada tanggal 14 Juni 2017, 15 Juni 2017 dan 16 Juni 2017. Kegiatan yang dilaksanakan pada tiap sesi didasarkan pada 4 tahapan yang perlu dilakukan dalam solution-focused brief therapy, yakni tahap 'Establishing Relationship', 'Determining Goals', 'Designing and Implementing Solutions' dan 'Focusing on Positive New Behaviours and Changes'.

\section{HASIL DAN PEMBAHASAN}

Total skor State Self-Esteem Scale (SSES) yang diperoleh kelima partisipan sebelum mengikuti intervensi berbeda dengan total skor yang didapat setelah mengikuti 6 sesi intervensi (lihat Tabel 1). Total skor dari tiga partisipan - CK, $M$ dan KL, mengalami peningkatan, sedangkan total skor dari dua partisipan - Y dan J, mengalami penurunan. CK, yang mendapatkan skor 67 pada pre-test, memperoleh skor 72 pada post-test. Skor $65 \mathrm{M}$ pada pre-test meningkat menjadi 68 pada post-test. Skor KL juga meningkat dari 62 pada pre-test menjadi 63 pada post-test. Y, yang mendapatkan skor 69 pada pre-test, memperoleh skor 63 pada post-test. Skor $68 \mathrm{~J}$ pada pre-test mengalami penurunan menjadi 66 pada post-test. Total skor dari kelima partisipan, baik pada pre-test maupun post-test, lebih rendah dari 76 (skor $<76 / 100$ ).

Empat dari lima partisipan memperoleh skor pre-test dan post-test yang berbeda pada domain sosial dari SSES (lihat Tabel 1). Dua partisipan - CK dan M, mendapatkan skor post-test yang 2 poin lebih tinggi dibandingkan skor pre-test, sedangkan Y dan $\mathrm{J}$ memperoleh skor post-test yang lebih rendah dibandingkan dengan skor pre-test. CK, yang mendapatkan skor 21 pada pre-test, memperoleh skor 23 pada post-test. Skor $23 \mathrm{M}$ pada pre-test meningkat menjadi 25 pada posttest. Y, yang mendapatkan skor 23 pada pre-test, memperoleh skor 22 pada post-test. Skor $25 \mathrm{~J}$ pada pre-test mengalami penurunan menjadi 23 pada post-test. Skor klien KL pada pre-test dan post-test tidak mengalami perubahan, yakni 22. Skor pada domain sosial dari kelima klien, baik pada pre-test maupun post-test, lebih rendah dari 26 (skor <26/35). 
Tabel 1. Skor Total dan Skor Domain Sosial SSES pada Pre-test dan post-test

\begin{tabular}{|c|c|c|c|c|c|c|c|c|c|c|}
\hline & \multicolumn{2}{|c|}{$C K$} & \multicolumn{2}{|c|}{$M$} & \multicolumn{2}{|c|}{$Y$} & \multicolumn{2}{|c|}{$J$} & \multicolumn{2}{|c|}{$K L$} \\
\hline & pre- & post- & pre- & post- & pre- & post- & pre- & post- & pre- & post- \\
\hline SSES: Skor total & 67 & 72 & 65 & 68 & 69 & 63 & 68 & 66 & 62 & 63 \\
\hline SSES: Domain sosial & 21 & 23 & 23 & 25 & 23 & 22 & 25 & 23 & 22 & 22 \\
\hline
\end{tabular}

Tidak ada perubahan signifikan pada mean dari skor total SSES kelompok pada post-test ketika dibandingkan dengan mean dari skor total SSES kelompok pada pre-test (lihat Grafik 1). Mean dari total skor SSES kelompok, baik pada pre-test maupun post-test, lebih rendah dari 76 (skor < 76/100).

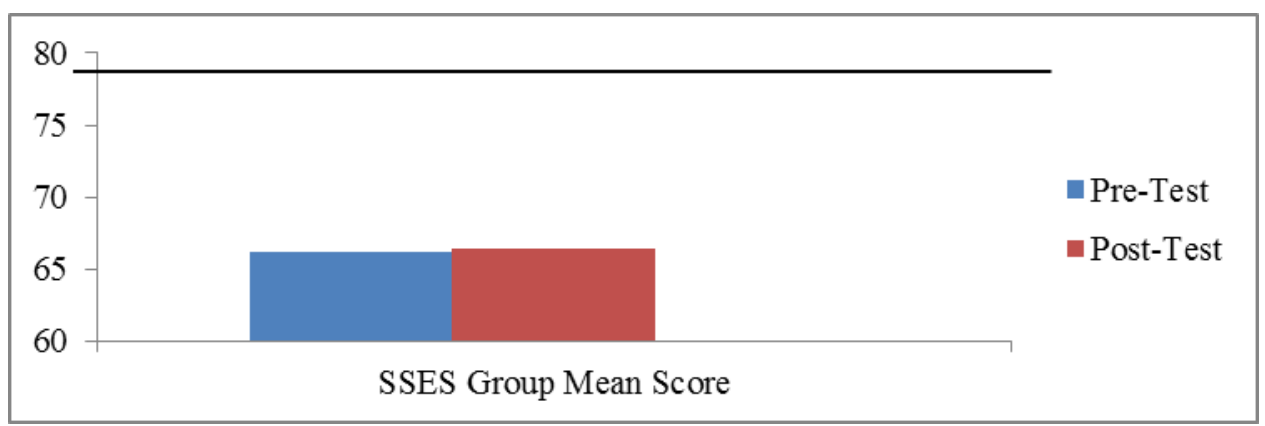

Grafik 1. Mean dari Skor total SSES kelompok pada pre-test dan post-test

\section{KESIMPULAN, DISKUSI DAN SARAN}

Intervensi kelompok ini dilakukan untuk meningkatkan self-esteem lima remaja putra yang merupakan anak asuh di Panti Asuhan X dengan menerapkan Solution-Focused Brief Group Therapy. Hasil post-test SSES menunjukkan bahwa hanya skor total dari 3 dari 5 partisipan yang mengalami peningkatan. Total skor yang diperoleh 2 partisipan lainnya mengalami penurunan. Tidak ada perubahan signifikan pada setiap hasil yang diperoleh. Berdasarkan hasil ini, dapat disimpulkan bahwa efektivitas dari Solution-Focused Brief Group Therapy untuk meningkatkan self-esteem dari lima remaja putra di Panti Asuhan X tergolong kurang.

Adapun beberapa faktor yang mempengaruhi hasil dari Solution-Focused Brief Group Therapy yang diterapkan untuk meningkatkan self-esteem kelima remaja laki-laki diantaranya hands-on activities yang disertakan selama sesi berlangsung, jenis intervensi - yakni intervensi kelompok, kondisi atau setting lokasi dimana kegiatan dilaksanakan, waktu pelaksanaan, jumlah sesi, serta kehadiran anak-anak asuh lain pada keenam sesi. Berbagai aktivitas, termasuk homework, yang memberikan kesempatan pada partisipan untuk mempraktikkan solusi-solusi yang telah dijelaskan dan didiskusikan dapat menghasilkan perubahan merupakan faktor pendekatan SFBT yang memiliki andil dalam hasil evaluasi intervensi (Brzezowksi, 2012). Jenis intervensi yang menghadirkan 4 partisipan lain juga mempengaruhi hasil evaluasi intervensi karena memberikan kesempatan pada tiap individu untuk belajar dari pengalaman orang lain serta umpan balik dari satu sama lain (Brabender, Fallon \& Smolar, 2004; Johnson, 2017).

Kondisi dari setting dimana keenam sesi diadakan - yakni ruang belajar kelompok SMP yang memiliki banyak jendela tanpa cara dan pendopo Panti Asuhan X yang dapat diakses dengan 
mudah oleh anak-anak asuh lain, serta waktu pelaksaanan keenam sesi dari pukul 15.00 hingga +/- 16.20 - yang merupakan waktu bermain anak, berpotensi menghadirkan berbagai extraneous variable (mis. extraneous variable auditori berupa teriakan dan tawa anak lain yang sedang bermain) yang dapat mempengaruhi atensi maupun kesungguhan partisipan (Magrabi, Li, Dunn \& Coerira, 2011; Sarafino, 2010). Jarak antar pelaksanaan sesi yang inkonsisten serta berbagai events yang berlangsung selama keenam sesi dilaksanakan, seperti ujian akhir sekolah dan latihan persiapan perayaan akbar Panti Asuhan X, merupakan faktor distraksi lain yang berpotensi mempengaruhi efektivitas dari intervensi kelompok. Jumlah sesi yang terbatas $(<8$ sesi) membatasi materi, termasuk aspek yang mempengaruhi self-esteem, yang dapat dicakup dalam proses terapi. Hal ini juga dapat mempengaruhi hasil evaluasi intervensi.

Terakhir, karakteristik - baik kekuatan (strengths) maupun kelemahan (weaknesses) dari alat ukur yang digunakan, yakni State Self-Esteem Scale, juga memiliki pengaruh terhadap hasil pengukuran self-esteem yang dilakukan sebelum dan setelah intervensi dilaksanakan. Sementara alat ukur State Self-Esteem Scale di satu sisi mengurangi potensi terjadinya interviewer bias, beberapa jenis bias seperti social desirability bias, habituation maupun tendency of neutral position mungkin terjadi dan mempengaruhi respons yang diberikan partisipan pada pre-test dan post-test dengan jarak waktu kurang dari 1 bulan (Neuman, 2014; Sarniak, 2015). Tidak dilakukannya uji validitas maupun reliabilitas untuk State Self-Esteem Scale terhadap populasi dengan karakteristik yang sama dengan kelima partisipan juga menimbulkan pertanyaan mengenai kesesuaian dari State Self-Esteem Scale untuk mengukur tingkat self-esteem partisipan.

Hasil temuan pada penelitian ini menambah jumlah literatur mengenai Solution-Focused Brief Group Therapy pada populasi remaja putra di panti asuhan yang hingga saat ini masih tergolong terbatas. Meskipun demikian, tidak ada penelitian yang sempurna. Adapun beberapa keterbatasan pada penelitian ini adalah tidak adanya control group pembanding serta jumlah sampel yang kecil ( $\mathrm{N}=1$ kelompok). Keterbatasan waktu dan biaya juga menyebabkan tidak diadakannya uji validitas dan reliabilitas untuk alat ukur yang digunakan. Alasan yang serupa juga berakibat pada jumlah sesi yang terbatas serta jarak antar sesi yang inkonsisten.

Saran untuk Penelitian Selanjutnya. Lima saran yang dapat dipertimbangkan untuk penelitian berikutnya, diantara lain: (a) Rangkaian sesi sebaiknya dilaksanakan dengan jarak antar sesi yang konsisten; (b) Setiap sesi sebaiknya dilaksanakan pada setting atau lokasi yang tidak berpotensi menghadirkan berbagai extraneous variable yang dapat mempengaruhi atensi maupun kesungguhan partisipan dalam mengikuti intervensi; (c) Sesi intervensi sebaiknya ditambah untuk meningkatkan jumlah materi yang dapat diberikan kepada partisipan; (d) Peneliti sebaiknya melaksanakan uji validitas dan reliabilitas untuk alat ukur yang akan digunakan pada populasi yang memiliki karakteristik yang sama dengan partisipan; (e) Peneliti merekrut jumlah sampel yang lebih besar dari beberapa panti asuhan.

\section{Ucapan Terima Kasih (Acknowledgement)}

Ucapan terima kasih kepada partisipan yang telah bersedia untuk diwawancara. Peneliti juga mengucapkan terima kasih kepada panti asuhan X yang bersedia menjadi objek penelitian. 


\section{REFERENSI}

Birndorf, S., Ryan, S., Auinger, P., \& Aten, M. (2005). High self-esteem among adolescents:

Longitudinal trends, sex differences, and protective factors. Journal of Adolescent Health, 37(3), 194-201.

Bean, R. A., Bush, K. R., McKenry, P. C., \& Wilson, S. P. (2003). The impact of parental support,behavioral control, and psychological control on the academic achievement and selfesteem of African American and European American adolescents. Journal of Adolescent Research, 18(5), 523-541.

Brabender, V. A., Fallon, A. E., \& Smolar, A. I. (2004). Essentials of group therapy. Hoboken, NJ: John Wiley \& Sons.

Heatherton, T. F., \& Polivy, J. (1991). Development and validation of a scale for measuring state self-esteem. Journal of Personality and Social Psychology, 60(6), 895-910.

Johnson, B. (2017). Psychotherapy: Understanding group therapy. Retrieved from http://www.apa.org/helpcenter/group-therapy.aspx

Kementerian Sosial Republik Indonesia, Save the Children \& UNICEF (2007). Someone that matters: The quality of care in childcare institutions in Indonesia. Jakarta: Save the Children UK, The Ministry of Social Affairs \& UNICEF.

Magrabi, F., Li, S. Y., Dunn, A. G., \& Coeira, E. (2011). Challenges in measuring the impact of interruption on patient safety and workflow outcomes. Methods of Information in Medicine, 50(5), 447-453.

Miller, T. (1984). Parental absence and its affects on adolescent self-esteem. International Journal of Social Psychiatry, 30(4), 293-196.

Mruk, C. J. (2006). Self-esteem research, theory and practice: Toward a positive psychology of self-esteem (3rd ed.). New York, NY: Springer Publishing Company.

Neuman, W. L. (2014). Social research methods: Qualitative and quantitative approaches (7th ed.). Essex: Pearson.

Orth, U., Robins, R. W., \& Roberts, B. W. (2008). Low self-esteem prospectively predicts depression in adolescence and young adulthood. Journal of Personality and Social Psychology, 95, 695-708.

Reasoner, R. W. (2002). Review of self-esteem research. Retrieved from http://www.selfesteem-nase.org/research.php

Rhodes, J., Roffan, J., Reddy, R., \& Fredriksen, K. (2004). Changes in self-esteem during the middle school years: A latent growth curve study of individual and contextual influences. Journal of School Psychology, 42, 243-261.

Sarniak, R. (2015, August). 9 types of research bias and how to avoid them. Quirk's Media. Retrieved from https://www.quirks.com/articles/9-types-of-research-bias-and-how-toavoid-them

Sarafino, E. P. (2014). Health psychology: Biopsychosocial interactions (7th ed.). Retrieved from https://books.google.co.id/books?id=m9hwDFOU1E8C\&pg=PT249\&lpg= PT249\&dq=source+of++external+distraction+during++psychological+intervention \&source=bl\& ots=5SxeTeJcVx\&sig=liAoofF8XKsqQzIoJjS02TopYX8\&hl=en\&sa=X\&ved=0ahUKE 
wi68d-1p-TUAhVJKY8KHXccDgsQ6AEIQjAF\#v=onepage \&q=source of external distraction during psychological intervention $\& \mathrm{f}=$ false

Taathadi, M. S. (2014). Application of solution-focused brief therapy (SFBT) to enhance high school students self-esteem: An embedded experimental design. International Journal of Psychological Studies. 6(3), 96-105.

Trzesniewski, K. H., Donnellan, M. B., Moffitt, T. E., Robins, R. W., Poulton, R., \& Caspi, A.

(2006). Low self-esteem during adolescence predicts poor health, criminal behavior, and limited economic prospects during adulthood. Developmental Psychology, 42, 381-390.

Twenge, J. M., \& Campbell, W. K. (2002). Self-esteem and socioeconomic status: A metaanalytic review. Personaity and Social Psychology Review, 6(1), 59-71.

Wells, K. R. (2016). Self-esteem. Retrieved from http://www.healthofchildren.com/S/Self-

Esteem.html.

Woolf, H. B., Artin, E., Crawford, F. S., Gilman, E. W., Kay, M. W., Pease Jr., R. W. (Eds.). (1976). Webster's new collegiate dictionary. Springfield, MA: G. \& C. Merriam. analytic review. Personality and Social Psychology Review, 6(1), 59-71. 